DOI: $10.20472 / B M .2018 .6 .2 .007$

\title{
THE ADVANTAGES OF USING BEST-WORST MODEL FOR HYBRID PRODUCTS
}

\author{
ANCA TAMAS, RUXANDRA POPESCU
}

\begin{abstract}
:
The aim of this paper is to find out if the country of origin of the hybrid products is important for specialists using the Best-Worst Model and to highlight the advantages of using it. It proved that using Best-Worst Model reduces the biases and eliminates the cultural differences associated with Likert or other rating scales. I used quantitative methods: questionnaires. For having a representative sample, I chose only respondents who have at home the products used in the study and, in the same time, who use the respective products in their professional activity. SPSS was used for computing the scores and to check out if the gender or age have an influence on the scores. It proved that, for specialists or consumers familiar with the products, country of origin is of low importance, it is less important comparing to price or quality and it doesn't have a significant effect on buying intention. In the case of all the analyzed products, the gender or the age of the respondents don't have a significant effect. The paper is very appropriate for researchers, it proved that Best-Worst Model is more objective than other types of survey. It provides a better level of efficiency and it increases the flexibility of the analyzed data. The main originality/value is the application of the Best-Worst Model on specific categories of hybrid products (cars, TV sets, mobile phones, sport shoes).
\end{abstract}

\section{Keywords:}

Best-Worst Model, consumer behavior

JEL Classification: B41, C83

\section{Authors:}

ANCA TAMAS, Center of International Business and Economics, Bucharest University of Economic Studies, Romania, Email: anca.tamas@rei.ase.ro RUXANDRA POPESCU, Bucharest University of Economic Studies, Romania, Email: ruxandra.popescu@rei.ase.ro

\section{Citation:}

ANCA TAMAS, RUXANDRA POPESCU (2018). The advantages of using Best-Worst Model for hybrid products. International Journal of Business and Management, Vol. VI(2), pp. 108-121., 10.20472/BM.2018.6.2.007 


\section{Introduction}

In assessing the consumer preferences, the widely used methods involve rating based scales for many years. Likert-type scale is the most popular scaling method, that includes the rating of attributes by the respondents. Each response category is labeled, sometimes using numbers (from -3 to +3 ), sometimes with adjectival descriptors (from not important to very important), sometimes only the endpoints are indicated, sometimes all the intermediate points are indicated.

The main bias in Likert-type questionnaires is that different respondents associate different meanings to the categories, thus the perceived distance between categories varies according the cultural background of the respondents (Crask and Fox, 1987). As a consequence, researches treat the categories as equal interval scales with precaution, bearing in mind that respondents tend to use only one part of the scale in their responses or that depending on the respondents' cultural background, some parts of the scale are more often used compared to other parts (Bachman and O'Malley, 1984). One problem in interpreting the results of rating scales questionnaires is the cultural differences of the respondents that strongly influence giving ratings (for example, if two respondents choose +2 category in a -3 to +3 rating scale, does not mean they give the same importance to a specific item) (Diamantopoulos et al., 2006), (Usunier and Lee, 2005). Another problem is comparing the results across countries or cultures, because some studies proved that people from US or Italy tend to use the endpoints of the scale more often than people from Japan, France or Australia do. (Lee et al., 2007), (Usunier and Lee, 2005). An important problem lies in the perceived distances between categories, as Cohen highlighted in 2003, a smaller problem refers to the position of attribute in the design of the questionnaire (placing the most important category in the left side would lead to higher agreement on this category according to Friedman et al. (1994)).

Best Worst Model (BWM), also known as maximum difference scaling, was used for the first time by Finn and Louviere in 1992 and ever since proved an empirical success, in spite of the lack of theoretical background for more than a decade.

In 2005, Marley and Louviere presented the theory behind the BWM and formally describe the cognitive processes used in choosing the best and the worst option, as well as the theoretical foundations of Best-Worst probabilistic models. They proved that using BWM questionnaires instead of rating scales questionnaires significantly reduce the biases usually associated with the rating scales, the social desirable responding, the positive-acquiescent response bias, extreme responding and mid-point responding to mention the most known biases (Cohen and Markowitz, 2002), Cohen and Neira, 2003) and, most of all, BWM eliminate the cultural differences in rating scales (Auger, 2007).

The main benefits of BWM are increasing the flexibility of the data analysis and producing a higher level of efficiency. Other obvious benefits of BWM are using a one-dimensional interval-scale of importance of attributes, therefore is easier to be understood by the respondents and also it better discriminates the level of importance the respondents associate with each attribute (Marley and Louviere 2005; Auger et al., 2007; Cohen et al., 2009; Goodman, 2009). 
When Finn and Louviere proposed using BWM back in 1992 they address and solve the main critiques of rating scale models:

- The respondents might not discriminate between items, thus multiple items might have a similar high importance and that is not realistic.

- The interpretation of rating scales values is difficult and even misleading ( a value of 4.2 over a 2.1 value does not necessary means the importance of the last item is half as the importance of the former).

- The reliability and validity of rating scales is frequently questionable.

BWM ask the respondent to choose the best option and the worst option from a set of attributes associated to a good or service. Therefore after examining each subset of attributes in a BWM questionnaire the respondent would choose a pair of attributes with a maximum difference, as each pair contents the best and the worst attribute.

According to (Flynn, 2010) there are three types of BWM, the object case (used to asses the preferences for a set of items), the profile or attribute case( the respondent evaluate one profile at a time) and the multi-profile case (the respondent evaluate several profiles at a time). The BWM object case is an alternative to the traditional rating scales, while the BWM attribute case as well as the BWM multi-profile case are alternatives to traditional choice-based conjoint analysis.

The BWM object case, also known as Case 1 BWM, was introduced in 1992 by Finn and Louviere and should be used when the aim of the research is assessing the relative values consumers associate with certain goods, services, brands or even public policies. First researches based on BWM used the $2^{\mathrm{J}}$ designs of the questionnaires (For $\mathrm{J}$ distinct objects should be considered $2^{J}$ distinct choice sets).

The BWM profile case or Case 2 BWS, which was introduced by Mclntosh and Louviere (2002) and ever since became popular in researches in health area. The respondent has to consider the attribute level describing a certain profile and to choose the best and the worst alternative among them.

The BWM multi-profile case or Case 3 BWS ask the respondent to choose the the best and the worst profile in a current choice set. It is considered closed to traditional DCE (Discrete Choice Experiment), it became the most popular of the three models. It was introduced by Flynn in 2010 and developed by Flynn and Marley in 2014.

The BWM was already used in a wide areas of research: public polling (Finn and Louviere, 1992), personal values (Bardi et al., 2009), ( Lee et al., 2008), consumer ethical beliefs and corporate social responsibility (Auger et al., 2007), consumer product attribute evaluations (Cohen and Markowitz, 2002),(Cohen, 2009), health care (Flynn et al., 2007), tourism motivations (Lee et al., 2006), food and health care (Cohen and Neira, 2003; Lee et al., 2008), the quality of care (Flynn et al., 2007), human rights, animal rights (Auger et al., 2004), food preferences (Jaeger et al., 2008), food values (Lusk and Briggeman, 2009), wine marketing (Goodman et al., 2005, 2008). 
Among empirical research body, dealing with the worst option and using the BWM was popular for the researchers willing to use an alternative to traditionally rating scales. After 2000 Case 2 BWM and Case 3 BWM were used mainly in health research.

At the beginning of its using the BWM was considered a very efficient method of collecting data, because allows to obtain more information from each respondent. Starting 2005 Marley built BWM on solid theoretical grounds and afterwards starting 2008 Louviere et al. reconsidered BWM as a collecting data method.

As any other methods, the BWM has some limitations

- the researcher could find the comparative value of items, but has little information about the absolute value of the items

- low flexibility, once the design of the questionnaire is set, cannot add any further items

-a bit unrealistic, as sometimes is difficult to choose the best and the worst option among and also make the choosing difficult if the respondent consider two items as being equally best or worst

- decision making processes could differ between the Best and Worst decisions

- cognitive difficulties in decision making process

\section{Body}

The main goal of this paper is to find out if the country of origin of the hybrid products (cars, TV sets, mobile phones, sport shoes) is important for specialists and, if yes, in which measure, using the Best-Worst Model. Another goal is to emphasize the advantages of using it for the researchers and for the consumers too. In order to assess the buying behavior using the Best-Worst Model, a BWM questionnaire was applied in two towns from one of the poorest EU region, namely the Vaslui county from Romania. The questionnaire was used in real buying places, like gas stations, car repair workshops, phone shops, sport shops, TV shops. The survey team chose only respondents who frequently use in their professional activity at least one of the following products: cars, TV sets, mobile phones, sport shoes and, in the same time, have in their families the above mentioned products. The questionnaires were self administrated. Out of 400 persons approached, 312 completed the questionnaires, a response rate of $78 \%$, and out of the 312 questionnaires, only 259 were completed correctly and accordingly to instructions. 
Tabel 1: The structure of the sample

\begin{tabular}{|l|l|l|}
\hline & Number & percent \\
\hline female & 131 & 50,57 \\
\hline male & 128 & 49,43 \\
\hline People up to 40 years old & 200 & 62,49 \\
\hline People over 40 years old & 59 & 37,51 \\
\hline Persons using frequently car at work & 75 & 28,57 \\
\hline Persons using frequently TV at work & 27 & 10,42 \\
\hline Persons using frequently mobile phone at work & 151 & 58,30 \\
\hline Persons using frequently sport shoes at work & 40 & 15,44 \\
\hline $\begin{array}{l}\text { Persons using frequently at work at least two of the above } \\
\text { mentioned products }\end{array}$ & 50 & 19,69 \\
\hline
\end{tabular}

Author's table based on the results from the questionnaires

The first four sentences refer at buying behavior, the following four sentences refer at product evaluation, the next four sentences refer at the consumers' opinion towards the studied products and the last four sentences refer at buying intention. The features for each of the four products were determined in a focus-group and were the quality, the price, the brand and country of origin for every product. The chosen model was BWM1 as described above. The formula for computing the scores is: $S=(T B-T W) / n f^{*} n v q$, where $S=$ the score, $\mathrm{TB}=$ the total of Best choices for an item, , TW= the total of Worst choices for an item, $\mathrm{nf}=$ the number of features chosen in the study, $\mathrm{nvq}=$ the number of valid questionnaires. The results are presented in table 2 and table 3.

\section{Table 2: The results for the Best feature}

\begin{tabular}{|l|l|l|l|l|}
\hline $\begin{array}{l}\text { The Best } \\
\text { feature for }\end{array}$ & Cars & TV sets & Mobile Phones & Sport Shoes \\
\hline $\begin{array}{l}\text { Buying } \\
\text { behavior }\end{array}$ & $\begin{array}{l}\text { The power of } \\
\text { the engine }\end{array}$ & $\begin{array}{l}\text { The quality of } \\
\text { the image }\end{array}$ & $\begin{array}{l}\text { Communication } \\
\text { facilities }\end{array}$ & $\begin{array}{l}\text { To be } \\
\text { comfortable } \\
\text { shoes }\end{array}$ \\
\hline evaluation & $\begin{array}{l}\text { To have all the } \\
\text { facilities }\end{array}$ & $\begin{array}{l}\text { A reasonable } \\
\text { price }\end{array}$ & The quality & endurance \\
\hline opinions & The quality of & Made by a top & The price of the & The material \\
\hline
\end{tabular}




\begin{tabular}{|l|l|l|l|l|}
\hline & the finishes & brand & subscription & $\begin{array}{l}\text { they are made } \\
\text { of }\end{array}$ \\
\hline $\begin{array}{l}\text { Buying } \\
\text { intention }\end{array}$ & $\begin{array}{l}\text { To have high } \\
\text { quality } \\
\text { technical } \\
\text { equipments }\end{array}$ & $\begin{array}{l}\text { To be a smart } \\
\text { TV }\end{array}$ & A high quality & $\begin{array}{l}\text { The quality of } \\
\text { the material }\end{array}$ \\
\hline
\end{tabular}

Author's table based on the results from the questionnaires

\section{Table 3: The results for the Worst feature}

\begin{tabular}{|l|l|l|l|l|}
\hline $\begin{array}{l}\text { The Worst } \\
\text { feature for }\end{array}$ & Cars & TV sets & Mobile Phones & Sport Shoes \\
\hline $\begin{array}{l}\text { Buying } \\
\text { behavior }\end{array}$ & The color & Promotions & $\begin{array}{l}\text { It is fashion to } \\
\text { have one }\end{array}$ & The color \\
\hline evaluation & The model & $\begin{array}{l}\text { If the } \\
\text { maintenance is } \\
\text { in the country }\end{array}$ & The design & Cheap price \\
\hline opinions & $\begin{array}{l}\text { The social } \\
\text { status } \\
\text { associated with }\end{array}$ & $\begin{array}{l}\text { The country of } \\
\text { fabrication }\end{array}$ & fashionable & $\begin{array}{l}\text { The country of } \\
\text { fabrication }\end{array}$ \\
\hline $\begin{array}{l}\text { Buying } \\
\text { intention }\end{array}$ & $\begin{array}{l}\text { Navigation } \\
\text { facilities }\end{array}$ & $\begin{array}{l}\text { Recording } \\
\text { facilities }\end{array}$ & Special offers & Attractiveness \\
\hline
\end{tabular}

Author's table based on the results from the questionnaires

Therefore, what matter most for the 259 respondents are the quality, the technical attributes, the facilities, the price, if it is made by a top brand. What matter least are the fashionable, the design, the social status, the low prices and the top brand. With respect to the four features we will mark (+) if the scores are positive, otherwise we will mark with $(-)$.

Table 4: The signs of the scores for the features

\begin{tabular}{|l|l|l|l|l|}
\hline & Cars & TV sets & $\begin{array}{l}\text { Mobile } \\
\text { Phones }\end{array}$ & Sport Shoes \\
\hline $\begin{array}{l}\text { Buying } \\
\text { behavior }\end{array}$ & $\begin{array}{l}\text { Country of } \\
\text { provenance }(+)\end{array}$ & Quality (+) & Brand (+) & Price (+) \\
\hline Evaluation & Brand (-) & Price (+) & Quality (+) & $\begin{array}{l}\text { Brand (-) } \\
\text { Country of origin } \\
(-)\end{array}$ \\
\hline Opinions & Quality (+) & $\begin{array}{l}\text { Country of } \\
\text { manufacturing (-) }\end{array}$ & Price (+) & Price (-) \\
\hline Buying & The country of & Quality (+) & Brand (-) & Quality (+) \\
\hline
\end{tabular}




\begin{tabular}{|l|l|l|l|l|}
\hline intention & $\begin{array}{l}\text { origin must be } \\
\text { strongly } \\
\text { developed (-) }\end{array}$ & Quality (+) & \\
\hline
\end{tabular}

Author's table based on the results from the questionnaires

We can see that, in the buying behavior, what matters most is the country of provenance for cars, the quality for TV sets, the brand for mobile phones and the price for sport shoes. In the evaluation of the products, brand is not so relevant in the case of cars and sport shoes and country of origin is not so relevant in the case of sport shoes too. Price is very relevant in the evaluation of TV sets and quality is very relevant in the evaluation of mobile phones. Regarding the respondents' opinions, country of manufacturing is not very important in the case of TV sets and price is not very important in the case of sport shoes. But quality is very important in the consumers' opinions regarding the cars and price is very important in the consumers' opinions regarding the mobile phones. Regarding the buying intention, it's not very important for consumers that the car is produced in a strongly developed country. Brand is not very important in the buying intention of mobile phones. But quality is very important in the buying intention of the TV sets, mobile phones and sport shoes.

Table 5: The scores for buying behavior

\begin{tabular}{|c|c|c|c|c|c|c|}
\hline & & Total & Female & Male & Young & Grown-up \\
\hline \multirow{4}{*}{$\overline{\widetilde{J}}$} & Promotion & 0,044 & 0,037 & 0,050 & 0,0428 & 0,048 \\
\hline & Country of origin & 0,004 & 0,022 & $-0,013$ & 0,005 & 0,002 \\
\hline & Engine power & 0,054 & 0,054 & 0,052 & 0,060 & 0,043 \\
\hline & Car color & $-0,103$ & $-0,115$ & $-0,089$ & $-0,109$ & $-0,095$ \\
\hline \multirow[b]{4}{*}{$\gtrless$} & Promotions & $-0,041$ & $-0,051$ & $-0,029$ & $-0,063$ & 0 \\
\hline & Image quality & 0,083 & 0,081 & 0,085 & 0,087 & 0,073 \\
\hline & Screen size & $-0,017$ & $-0,028$ & $-0,005$ & $-0,011$ & $-0,027$ \\
\hline & Modern look & $-0,024$ & $-0,001$ & $-0,050$ & $-0,011$ & $-0,046$ \\
\hline \multirow{3}{*}{$\begin{array}{l}\frac{0}{\overline{0}} \\
\frac{0}{\Sigma}\end{array}$} & Fidelity points & $-0,033$ & $-0,022$ & $-0,044$ & $-0,053$ & 0 \\
\hline & Tradition of the brand & $-0,011$ & 0,005 & $-0,027$ & $-0,004$ & $-0,021$ \\
\hline & Fashionable & $-0,044$ & $-0,054$ & $-0,036$ & $-0,029$ & $-0,073$ \\
\hline
\end{tabular}




\begin{tabular}{|c|c|c|c|c|c|c|}
\hline & $\begin{array}{l}\text { Facilitations of } \\
\text { communication }\end{array}$ & 0,089 & 0,071 & 0,108 & 0,087 & 0,095 \\
\hline \multirow{4}{*}{ 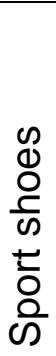 } & Price & $-0,027$ & $-0,020$ & $-0,031$ & $-0,044$ & 0,008 \\
\hline & Color & $-0,053$ & $-0,039$ & $-0,067$ & $-0,045$ & $-0,065$ \\
\hline & Design & $-0,046$ & $-0,051$ & $-0,040$ & $-0,045$ & $-0,051$ \\
\hline & Comfortable & 0,126 & 0,111 & 0,139 & 0,136 & 0,108 \\
\hline
\end{tabular}

Author's table based on the results from the questionnaires

In the buying intention of cars, we can see that the engine power is the most important and the car color the least important feature for all the categories. For TV sets, image quality is the most important, while the promotions and the modern look are less important. For mobile phones, facilitations of communication is by far the most important feature. For the respondents, it seems it's not very relevant if the mobile phone is fashionable or not. For sport shoes, what matters most is, by far, to be comfortable. The color or the design are of low importance.

Table 6: The scores for evaluation

\begin{tabular}{|c|c|c|c|c|c|c|}
\hline & & Total & Female & Male & Young & Grown-up \\
\hline \multirow[b]{4}{*}{$\overline{\widetilde{J}}$} & A known brand & $-0,031$ & $-0,032$ & $-0,032$ & $-0,025$ & $-0,046$ \\
\hline & All facilities & 0,069 & 0,062 & 0,079 & 0,065 & 0,078 \\
\hline & Endowments & 0,027 & 0,022 & 0,031 & 0,016 & 0,051 \\
\hline & Model & $-0,065$ & $-0,053$ & $-0,077$ & $-0,056$ & $-0,084$ \\
\hline \multirow[b]{4}{*}{$\gtrless$} & Reasonable price & 0,042 & 0,035 & 0,050 & 0,036 & 0,051 \\
\hline & Warrant & $-0,007$ & $-0,007$ & $-0,009$ & $-0,020$ & 0,019 \\
\hline & Repair in the country & $-0,043$ & $-0,037$ & $-0,048$ & $-0,042$ & $-0,043$ \\
\hline & Sound quality & 0,008 & 0,009 & 0,007 & 0,025 & $-0,027$ \\
\hline \multirow{4}{*}{$\begin{array}{l}\frac{0}{c} \\
\frac{0}{0} \\
\frac{1}{2} \\
\frac{0}{\overline{0}} \\
\frac{0}{2}\end{array}$} & Design & $-0,072$ & $-0,064$ & $-0,079$ & $-0,063$ & $-0,089$ \\
\hline & Quality & 0,066 & 0,073 & 0,062 & 0,068 & 0,062 \\
\hline & Extra endowments & $-0,028$ & $-0,032$ & $-0,029$ & $-0,036$ & $-0,016$ \\
\hline & The quality price ratio & 0,034 & 0,022 & 0,046 & 0,032 & 0,043 \\
\hline
\end{tabular}




\begin{tabular}{|c|c|c|c|c|c|c|}
\hline \multirow{4}{*}{$\begin{array}{l}\text { D } \\
\text { O } \\
\text { क } \\
\frac{1}{0} \\
\text { के }\end{array}$} & Endurance & 0,111 & 0,102 & 0,122 & 0,110 & 0,114 \\
\hline & Country of origin & $-0,050$ & $-0,066$ & $-0,032$ & $-0,041$ & $-0,065$ \\
\hline & Top brands & $-0,007$ & 0,009 & $-0,027$ & 0,001 & $-0,024$ \\
\hline & Cheap price & $-0,054$ & $-0,045$ & $-0,062$ & $-0,071$ & $-0,024$ \\
\hline
\end{tabular}

Author's table based on the results from the questionnaires

In the evaluation of the cars, brand had a low importance. These results might be explained by the fact that the respondents are from one of the poorest region in EU, therefore the possibilities of purchasing a car made by a top brand or in a developed country are pretty low.

For TV sets and mobile phones, the quality and the price are important in evaluation. Romanian people prefer, generally, quality TV sets and mobile phones at reasonable prices, other features being at lower importance.

Regarding the low technology hybrid products, like sport shoes, endurance is very important, other features being less important in evaluation.

Table 7: The scores for opinions regarding the product

\begin{tabular}{|c|c|c|c|c|c|c|}
\hline & & Total & Female & Male & Young & Grown-up \\
\hline \multirow[b]{4}{*}{ 心 } & Finishes quality & 0,054 & 0,056 & 0,052 & 0,056 & 0,048 \\
\hline & Price facilities & $-0,021$ & $-0,022$ & $-0,017$ & $-0,031$ & $-0,005$ \\
\hline & $\begin{array}{l}\text { If the brand is representative in the } \\
\text { country }\end{array}$ & 0,027 & 0,018 & 0,032 & 0,035 & 0,013 \\
\hline & Social status & $-0,059$ & $-0,053$ & $-0,067$ & $-0,060$ & $-0,057$ \\
\hline \multirow[b]{4}{*}{$\gtrless$} & Country of fabrication & $-0,035$ & $-0,022$ & $-0,050$ & $-0,039$ & $-0,027$ \\
\hline & Made by top brand & 0,032 & 0,017 & 0,048 & 0,053 & $-0,008$ \\
\hline & The size & $-0,028$ & $-0,026$ & $-0,031$ & $-0,029$ & $-0,029$ \\
\hline & Large warrant & 0,031 & 0,032 & 0,032 & 0,016 & 0,065 \\
\hline \multirow{3}{*}{$\frac{\frac{0}{\overline{0}}}{\frac{0}{2}}$} & The look & 0 & $-0,011$ & 0,011 & 0,002 & $-0,008$ \\
\hline & Fashionable & $-0,022$ & $-0,020$ & $-0,025$ & $-0,026$ & $-0,013$ \\
\hline & New generation & 0,003 & 0,020 & $-0,011$ & 0,022 & $-0,027$ \\
\hline
\end{tabular}




\begin{tabular}{|c|c|c|c|c|c|c|}
\hline & The subscription price & 0,018 & 0,011 & 0,025 & 0,001 & 0,048 \\
\hline \multirow{4}{*}{$\begin{array}{l}\mathscr{D} \\
\searrow \\
\frac{D}{0} \\
\text { के } \\
\frac{1}{0} \\
\text { की }\end{array}$} & The price & $-0,018$ & $-0,018$ & $-0,019$ & $-0,035$ & 0,010 \\
\hline & The material & 0,067 & 0,066 & 0,071 & 0,071 & 0,065 \\
\hline & The brand & $-0,042$ & $-0,043$ & $-0,040$ & $-0,038$ & $-0,051$ \\
\hline & Their look & $-0,006$ & $-0,003$ & $-0,011$ & 0,002 & $-0,024$ \\
\hline
\end{tabular}

Author's table based on the results from the questionnaires

For hybrid products, expensive and involving high technology, like cars, quality is important in the opinions of the respondents, country of origin is an important feature when the cars were bought, fact which implies a mental analogy between the two features in the buying behavior.

For other hybrid products also involving high technology, like TV sets and mobile phones, the quality and the price are important in the opinions of the respondents.

Regarding the low technology hybrid products, like sport shoes, the price and the quality are important too, other features are of lower importance in the respondents' opinions.

Table 8: The scores for buying intention

\begin{tabular}{|c|c|c|c|c|c|c|}
\hline & & Total & Female & Male & Young & $\begin{array}{l}\text { Grown- } \\
\text { up }\end{array}$ \\
\hline \multirow[b]{4}{*}{ Uू } & $\begin{array}{l}\text { Made in a developed } \\
\text { country }\end{array}$ & $-0,022$ & $-0,032$ & $-0,013$ & $-0,038$ & 0,010 \\
\hline & High quality endowments & 0,091 & 0,085 & 0,096 & 0,103 & 0,065 \\
\hline & Navigation facilities & $-0,033$ & $-0,020$ & $-0,044$ & $-0,032$ & $-0,035$ \\
\hline & Good looking & $-0,035$ & $-0,032$ & $-0,038$ & $-0,032$ & $-0,040$ \\
\hline \multirow[b]{4}{*}{$\gtrless$} & Modern & $-0,012$ & $-0,035$ & 0,009 & $-0,010$ & $-0,019$ \\
\hline & Smart & 0,048 & 0,056 & 0,038 & 0,073 & 0,005 \\
\hline & Recording facilities & $-0,062$ & $-0,058$ & $-0,063$ & $-0,068$ & $-0,054$ \\
\hline & Quality workmanship & 0,027 & 0,037 & 0,015 & 0,004 & 0,067 \\
\hline \multirow{2}{*}{$\begin{array}{l}\frac{0}{0} \\
\frac{0}{2}\end{array}$} & Price cut & $-0,002$ & $-0,013$ & 0,007 & $-0,014$ & 0,019 \\
\hline & Top brand design & $-0,013$ & $-0,001$ & $-0,029$ & 0,013 & $-0,067$ \\
\hline
\end{tabular}




\begin{tabular}{|c|c|c|c|c|c|c|}
\hline & Special offer & $-0,037$ & $-0,030$ & $-0,042$ & $-0,047$ & $-0,016$ \\
\hline & High quality & 0,055 & 0,045 & 0,063 & 0,048 & 0,065 \\
\hline \multirow{4}{*}{ 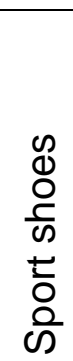 } & Quality material & 0,073 & 0,053 & 0,093 & 0,063 & 0,092 \\
\hline & Known brand & 0,015 & 0,011 & 0,019 & 0,026 & $-0,008$ \\
\hline & Likeability & 0,049 & 0,045 & 0,052 & 0,054 & 0,040 \\
\hline & Attractiveness & $-0,138$ & $-0,109$ & $-0,164$ & $-0,144$ & $-0,125$ \\
\hline
\end{tabular}

Author's table based on the results from the questionnaires

\section{Legend: the highest scores are in bold, the lowest scores are in bold italic}

For the buying intention, the level of development of the country of origin of the cars is less relevant. These results might be explained by the fact that the respondents are from a poor region, so they don't afford to purchase an expensive car, made in a developed country.

For TV sets and mobile phones, the quality and the price are important in buying intention too. The minus sign for brand in buying intention for mobile phones might be explained by the fact that, lately, on the Romanian market, we can find a large offer of mobile phones, made by brands which are not very famous, but with a good quality and at reasonable prices. In the case of the sport shoes, the quality material is much more important than the attractiveness.

SPSS was used for computing the scores and to check out if the gender or age have an influence on the scores. Due to high value of the Levene test and of the significance level, homogeneity assumption of variation was not violated, therefore gender or age do not have a high significance on scores.

\section{Conclusions}

In the case of special hybrid products, expensive and with high technology, like cars, the quality is the most important feature, while the brand and the country of origin of the car are less important. The results are influenced by the fact that the respondents are from a poor region and they don't afford cars from developed countries or from top brands.

Almost the same situation in the case of hybrid products with high technology, but not as expensive as the cars, like the TV sets and the mobile phones, the quality and the price are the most important, while the brand and the country of fabrication are less important.

In the case of cheap hybrid products, with low technology, like sport shoes, the quality and the price are the most important too, while other features are of low importance. 
In the case of all the analyzed products (cars, TV sets, mobile phones, sport shoes), country of origin is not so important in the buying intention and the gender or the age of the respondents don't have a significant effect too.

The findings are similar to Parameswaran \& Yaprak's (1987), namely for specialists or consumers familiar with products, country of origin is of low importance. The results also support the Elliot \& Cameron's results (1994), meaning the country of origin is less important comparing to price or quality and are congruent with the Kotler \& Gertner's results (2002), namely the country of origin doesn't have a significant effect on buying intention. The findings do not support the Kleppe, Iversen \& Stensaker's results (2002), the buying intention is greater for products made in developed countries.

Best-Worst Model helped us to quantify the features of the hybrid products from the perspective of the consumers familiar with the chosen products, in a transparent and accessible manner for the respondents and for the test administrators.

\section{References}

Auger, P., Devinney, T.M. and Louviere, J.J. (2004), Consumer's social beliefs, an international investigation using best worst scaling methodology, working paper, University of Melbourne, Melbourne Business School, Melbourne.

Auger, P., Devinney, T.M. and Louviere, J.J. (2007), Using best-worst scaling methodology to investigate consumer ethical beliefs across countries, Journal of Business Ethics, 70(3), 299-326. https://doi.org/10.1007/s10551-006-9112-7

Bachman, J.G. and O'Malley, P.M. (1984), Yea-saying, nay-saying, and going to extremes: Black-White differences in response style, The Public Opinion Quarterly, 48(2), 491-509. https://doi.org/10.1086/268845

Bardi, A., Lee, J.A., Hofmann-Towfigh, N. and Soutar, G. (2009), The structure of intra-individual value change, Journal of Personality and Social Psychology, 97(5), 913-29. https://doi.org/10.1037/a0016617

Cohen, S.H. and Markowitz, P. (2002), Renewing market segmentation: some new tools to correct old problems, ESOMAR, Amsterdam, pp. 595-612.

Cohen, S.H. and Neira, L. (2003), Measuring preference for product benefits across countries: overcoming scale usage bias with maximum difference scaling, paper presented at the ESOMAR 2003 Latin America Conference, Amsterdam.

Cohen, E. (2009), Applying best-worst scaling to wine marketing, International Journal of Wine Business Research, 21(1), 8-23. https://doi.org/10.1108/17511060910948008

Cohen, E, d'Hauteville, F and Siriex, L (2009), A cross-cultural comparison of choice criteria for wine in restaurants, International Journal of Wine Business Research, 21(1), 50-62. https://doi.org/10.1108/17511060910948035 
Crask, M.R. and Fox, R.J. (1987), An exploration of the interval properties of three commonly used marketing research studies: a magnitude estimation approach, Journal of the Marketing Research Society, 29(3), 317-39.

Diamantopoulos, A., Reynolds, N. L., \& Simintiras, A. C. (2006). The impact of response styles on the stability of cross-national comparisons. Journal of Business Research, 59, 925-935. https://doi.org/10.1016/j.jbusres.2006.03.001

Elliott, G. R., \& Cameron, R. C., (1994), Customer Perception of Product Quality and the Country-of-Origin Effect, Journal of International Marketing, 49-62.

Finn, A. and Louviere, J.J. (1992), Determining the appropriate response to evidence of public concern: the case of food safety, Journal of Public Policy and Marketing, 11, $19-25$.

Flynn, T.N., Louviere, J.J., Peters, T.J. and Coast, J. (2007), Best-worst scaling: what it can do for health care research and how to do it, Journal of Health Economics, 26(1), 171-89. https://doi.org/10.1016/j.jhealeco.2006.04.002

Flynn, T.N. (2010). Valuing citizen and patient preference in health: recent developments in three types of best-worst scaling. Expert Review of Pharmacoeconomics \& Outcomes Research, 10, 259-267. https://doi.org/10.1586/erp.10.29

Flynn, T. N., \& Marley, 2014, A. A. J. (submitted). Best-worst scaling: Theory and methods. In S. Hess \& A. Daly (Eds.), Handbook of Choice Modelling.

Friedman, H., Herskovitz, P., \& Pollack, S. (Eds.) (1994), Biasing Effects of Scale-checking Style in Response to a Likert Scale. Proceedings of the American Statistical Association Annual Conference: Survey Research Methods.

Goodman, S., Lockshin, L. and Cohen, E. (2005), "Best worst scaling: a simple method to determine drinks and wine style preferences", paper presented at the 2nd Annual International Wine Marketing Symposium, Sonoma State University, Rohnert Park, CA, 8-9 July.

Goodman, S., Lockshin, L. and Cohen, E. (2008), Examining market segments and influencers of choice for wine using the best worst choice method, Revenue Internationale des Sciences Sociales - Special Wine Marketing Edition, 8(1), 94-112.

Goodman, S (2009), An international comparison of retail consumer wine choice, International Journal of Wine Business Research, 21(1), 41-49. https://doi.org/10.1108/17511060910948026

Jaeger, S.R., Jørgensen, A.S., Aaslyng, M.D. and Bredie, W.L.P. (2008), Best-worst scaling: an introduction and initial comparison with monadic rating for preference elicitation with food products, Food Quality and Preferences, 19, 579-588. https://doi.org/10.1016/j.foodqual.2008.03.002

Kleppe, I. A., Iversen, N. M., \& Stensaker, I. G., (2002), Country images in marketing strategies: Conceptual issues and an empirical Asian illustration, Journal of Brand Management 10(1), 61-74. https://doi.org/10.1057/palgrave.bm.2540102

Kotler, P. and Gertner, D., (2002), Country as Brand, Product, and Beyond: A Place Marketing and Brand Management Perspective, Journal of Brand Management, 9, 62-67. https://doi.org/10.1057/palgrave.bm.2540076 
Lee, J.A., Soutar, G.N., Louviere, J.J. and Daly, T.M. (2006), An examination of the relationship between values and holiday benefits across cultures using ratings scales and best-worst scaling, paper presented at the Australian and New Zealand Marketing Academy Conference, Brisbane.

Lee, J.A., Soutar, G.N. and Louviere, J.J. (2007), Measuring values using best-worst scaling: the LOV example, Psychology and Marketing, 24(12), 1043-58. https://doi.org/10.1002/mar.20197

Lee, J.A., Soutar, G.N. and Louviere, J.J. (2008), The best-worst scaling approach: an alternative to Schwartz's values survey, Journal of Personality Assessment, 90(4), 335-47. https://doi.org/10.1080/00223890802107925

Lusk, JL and Briggeman, BC (2009), Food value, American Journal of Agricultural Economics, 91(1), 184196. https://doi.org/10.1111/j.1467-8276.2008.01175.x

Marley, A.A.J. and Louviere, J.J. (2005), Some probabilistic models of best, worst, and best-worst choices, Journal of Mathematical Psychology, 49, 464-80. https://doi.org/10.1016/j.jmp.2005.05.003

Parameswaran, R., \& Yaprak, A., (1987). A Cross-National Comparison of Consumer Research Measures., $\begin{array}{llll}\text { Journal of International Business Studies, } & \text { 18(Spring), }\end{array}$ https://doi.org/10.1057/palgrave.jibs.8490398

Usunier, J. C., \& Lee, J. A. (2005). Marketing across cultures. Essex, UK: Pearson Education. 